\title{
First-person plural in Prince Edward Island Acadian French: The fate of the vernacular variant je...ons
}

\author{
R U T H K I N G \\ York University \\ TER R Y N A D A S D I \\ University of Alberta \\ G A R Y R. B U T L E R \\ York University
}

\section{A B S T R AC T}

In Atlantic Canada Acadian communities, definite on is in competition with the traditional vernacular variant je...ons (e.g., on parle vs. je parlons "we speak"), with the latter variant stable only in isolated communities, but losing ground in communities in which there is substantial contact with external varieties of French. We analyze the distribution of the two variants in two Prince Edward Island communities that differ in terms of amount of such contact. The results of earlier studies of Acadian French are confirmed in that je... ons usage remains robust in the more isolated community but is much lower in the less isolated one. However, in the latter community, the declining variant, while accounting for less than $20 \%$ of tokens for the variable, has not faded away. Although it is not used at all by some speakers, it is actually the variant of choice for others, and for still other speakers, it has taken on a particular discourse function, that of indexing narration. Comparison with variation in the third-person plural, in which a traditional variant is also in competition with an external variant, shows that the decline of je...ons is linked to its greater saliency, making it a prime candidate for social reevaluation.

Studies of both Canadian (e.g., Laberge, 1977; Thibault, 1991) and European French (e.g., Coveney, 2000) show that definite on has almost entirely supplanted the standard first-person plural subject clitic nous in informal French. ${ }^{1}$ Indeed, it has been argued that for isolated varieties of French that have had little or no contact with the standard, the nous variant has probably never existed as a subject clitic (see Coveney, 2000:453 for a discussion). This is most likely the case for vernacular Atlantic Canada Acadian French. Our own studies of varieties spoken

An earlier version of this article was presented at UKLVC-3, held in July 2001 at the University of York, U.K. We thank audience members for comments. We also thank Raymond Mougeon, along with this journal's anonymous referees, for useful comments on an earlier written version. The research was funded by standard research grants awarded to King and Nadasdi by the Social Sciences and Humanities Research Council of Canada. 
in the provinces of Prince Edward Island and Newfoundland, along with those of Flikeid (1989) for varieties in the province of Nova Scotia, reveal no instances of subject nous in either formal or informal style in large sociolinguistic corpora. In Acadian communities, on is in competition with the traditional vernacular variant, je...ons, as shown in (1). ${ }^{2}$

(1) a. Je faisions trop de tricks quasiment.

'We used to play almost too many tricks.'

b. On faisait plus des tours qui faisaient de la fun.

'We used to play more tricks which were for fun.'

In this article, we examine first-person plural pronominal usage in two varieties of Prince Edward Island French, those of the communities Abram-Village and Saint-Louis, to see whether or not on is in the process of replacing the traditional variant, thereby bringing these Acadian varieties in line with other varieties of Canadian French. We will consider the distribution of the two variants across social categories and also across individual speakers.

\section{B A C K G R O U N D}

According to Brunot (1967:335), je... ons began to be replaced in French in the 16th century. Although it is not to our knowledge attested in (earlier) Quebec French, the geographical distribution of je...ons actually remained widespread in France up to the late 19th century. Flikeid and Péronnet (1989) reported that the Atlas linguistique de la France (1902-1910) shows that most northern varieties still retained je...ons (with $o(z)$ occurring in Picardy and on occurring in the northwest) at the turn of the 20 th century. ${ }^{3}$ In Atlantic Canada, recent studies have found that je...ons, typically considered one of the most salient markers of Acadian French, remains the most frequent variant only in those Acadian communities that exhibit low normative pressure from external varieties, particularly, francophone communities in the provinces of Nova Scotia and Newfoundland (Flikeid \& Péronnet, 1989; King \& Nadasdi, 1999). In some areas of Atlantic Canada, such as northeastern New Brunswick, it has disappeared altogether (Beaulieu \& Cichocki, 2003).

In our survey of the literature, we noted a link between the survival of je... ons and the survival of the third-person plural traditional variant ils...ont (e.g., ils parlont "they speak" vs. the standard ils parlent, where the ending is phonetically null). ${ }^{4}$ In the most conservative Acadian communities (e.g., L'Anse-à-Canards, Newfoundland), usage of the first- and third-person traditional variants approaches categorality (King, 1989). However, Flikeid and Péronnet (1989) reported the same proportion of je...ons and ils... ont in one of five Nova Scotia communities they studied, but somewhat more ils...ont than je...ons in the remaining four communities (e.g., $72 \%$ ils... ont, but $56 \%$ je ... ons in Baie Ste-Marie, Nova Scotia). In communities where ils... ont is marginal, as in northeastern New Brunswick (Beaulieu \& Cichocki, 2003) and in French Louisiana (Dubois, King, \& Nadasdi, 2003), je...ons is not attested. 
TABLE 1. Distribution of je... ons versus on by community

\begin{tabular}{lrr}
\hline \hline Community & je...ons & \multicolumn{1}{c}{ on } \\
\hline Abram-Village & $488(18 \%)$ & $2158(82 \%)$ \\
Saint-Louis & $1473(76 \%)$ & $453(24 \%)$ \\
\hline
\end{tabular}

METHODOLOGY

Our data come from a large corpus of sociolinguistic interviews recorded in 1987 with 44 residents of two small villages in Prince Edward Island. Although French is a minority language in Prince Edward Island, there is one region, Évangéline, that constitutes a French enclave, wherein French is the majority language in a number of small villages. The French of one of those villages, Abram-Village, was chosen for study. There the situation is one of stable language maintenance, with considerable institutional support for French, with most services, such as shops, church, and the post office provided in French, along with French firstlanguage education. The second village chosen, Saint-Louis, is located in Tignish region, where the situation is one of language shift, with French largely restricted to the speech of middle-aged and older residents, and to high-school students enrolled in "French immersion" programs aimed at second-language learners of French. In each community, local residents born and raised in the community conducted sociolinguistic interviews of at least 90 minutes' duration. For the present study, interviews for 22 individuals, representative of the age range of the larger sample and representing both sexes, were analyzed. The interview data for these 22 speakers provided 4572 tokens of first-person plural pronouns with definite reference. Following standard sociolinguistic methodology, cases of indefinite on (e.g., on sait jamais ... 'one never knows'), which do not represent instances of the variable, along with ambiguous cases with respect to the definite/ indefinite distinction, were eliminated from the data set.

\section{VARIATION AT THE LEVEL OF THE COMMUNITY}

Table 1 shows the distribution of the two first-person plural pronominal variants by community. We see that use of je... ons is limited in Abram-Village, where the vast majority of tokens contain on, but it has wide currency in Saint-Louis; although it must be noted that nearly a quarter of all Saint-Louis tokens do involve on. When we compare these results to those for a comparable number of tokens for the third-person plural variable $(n=4892)$, we find that the traditional variant (ils...ont) occurs with $78 \%$ frequency in Abram-Village and $83 \%$ in SaintLouis. ${ }^{5}$ Thus, these results are in line with those of earlier studies: ils... ont occurs with close to the same frequency as je... ons in Saint-Louis, but is far more frequent than je... ons in Abram-Village. We will consider why such a difference between the two traditional variants might arise. 
TABLE 2. Overall results for Abram-Village

\begin{tabular}{|c|c|c|c|}
\hline & je...ons & Factor Weight & Tokens \\
\hline \multicolumn{4}{|l|}{ Age } \\
\hline $15-21$ & $45(11 \%)$ & .362 & 402 \\
\hline $26-42$ & $203(20 \%)$ & .530 & 1015 \\
\hline $46-61$ & $152(20 \%)$ & .534 & 750 \\
\hline $66-81$ & $88(18 \%)$ & .503 & 480 \\
\hline \multicolumn{4}{|l|}{ Sex } \\
\hline Female & $155(11 \%)$ & .380 & 1374 \\
\hline Male & $333(26 \%)$ & .629 & 1273 \\
\hline \multicolumn{4}{|l|}{ Language use } \\
\hline French $=$ English & $0 \quad(0 \%)$ & knockout & 204 \\
\hline French $>$ English & $488(20 \%)$ & & 2443 \\
\hline \multicolumn{4}{|l|}{ French education } \\
\hline No French ed. & $n a$ & $n a$ & $n a$ \\
\hline French ed., grades $1-8$ & $305(32 \%)$ & .709 & 941 \\
\hline French ed., grades 1-12 & $183(11 \%)$ & .380 & 1706 \\
\hline \multicolumn{4}{|l|}{ Marketplace } \\
\hline Least standard French & $354(27 \%)$ & .762 & 1292 \\
\hline More standard French & $132(16 \%)$ & .626 & 803 \\
\hline Most standard French & $2(0 \%)$ & .030 & 552 \\
\hline
\end{tabular}

Note: $n a=$ not available.

In the quantitative analysis of the variable, a number of social factors were taken into consideration that have been shown to condition variation in both majority and minority speech communities, including age, sex, community, language use, French language education, and speakers' position in the linguistic marketplace (cf., King \& Nadasdi, 1996; Mougeon \& Nadasdi, 1998). Given the different status of French in the two communities, it was necessary to perform separate multivariate analyses for each community, which was achieved in a number of independent runs of GOLDVARB-2. Table 2 presents the results for AbramVillage. For this community, robust results were obtained for position in the linguistic marketplace, that is, with "how speakers' economic activity, taken in its widest sense, requires or is necessarily associated with competence in the legitimized (or standard, elite, educated, etc.) language" (Sankoff \& Laberge, 1978, following Bourdieu). Those speakers with higher marketplace scores tended to use more on and those with lower scores used more je...ons.

The Saint-Louis results are somewhat different, as there is little division among speakers in terms of marketplace. Because, with very few exceptions, only students enrolled in French immersion classes can be said to be influenced by nonvernacular French, the marketplace variable was not included in the analysis of the Saint-Louis data. ${ }^{6}$ Here, the amount of French language education emerged as significant, that is, speakers with higher levels of education used the on variant more frequently. These results are presented in Table 3. 
TABLE 3. Overall results for Saint-Louis

\begin{tabular}{lccc}
\hline \hline & $j e \ldots$ ons & Factor Weight & Tokens \\
\hline Age & $n a$ & $n a$ & \\
$15-21$ & $511(96 \%)$ & .842 & $n a$ \\
$26-42$ & $668(73 \%)$ & .364 & 531 \\
$46-61$ & $294(61 \%)$ & .247 & 913 \\
$66-81$ & & & 482 \\
Sex & $1068(94 \%)$ & .786 & 1142 \\
Female & $405(52 \%)$ & .214 & 784 \\
Male & & & \\
Language use & $962(78 \%)$ & .531 & 1231 \\
French = English & $511(74 \%)$ & .469 & 695 \\
French > English & & .820 & 1747 \\
French education & $1440(82 \%)$ & .180 & $n a$ \\
$\quad$ No French ed. & $33(18 \%)$ & $n a$ & $n a$ \\
French ed., grades 1-8 & $n a$ & $n a$ & $n a$ \\
French ed., grades 1-12 & $n a$ & $n a$ & $n a$ \\
Marketplace & $n a$ & $n a$ & $n a$ \\
Least standard French & $n a$ & & \\
More standard French & & & \\
Most standard French & & & \\
\hline \hline
\end{tabular}

These results are not surprising and mirror the findings of previous work on a number of other morphosyntactic variables in the two communities (cf., King \& Nadasdi, 1996). The vernacular variant has much greater currency in SaintLouis, where external varieties of French have had significantly less impact, as noted previously.

Of the remaining social variables, the most interesting is the differing contributions of speaker sex in the two communities. In Abram-Village, men more so than women favor the traditional variant, but in Saint-Louis, the star traditionbearers are women: fully $94 \%$ of their tokens involve je... ons. This difference is understandable when one considers the sociolinguistic structure of each community. Following Eckert and McConnell-Ginet (1992), we interpret the sociolinguistic behavior of women (and men) within the local context, examining the roles of women in the two communities. In Abram-Village, women are employed in a variety of occupations and take part in voluntary activities in which normative French has status (e.g., school secretary, night school teacher, member of the community theatrical group, etc.). In Saint-Louis, most women do not work outside the home, and, if they do, they work at jobs that are conducted in English. Although the Saint-Louis women are clearly fluent speakers of the Acadian variety, both participant observation and self-report data indicate that they have less contact with external varieties of French than do all the other members of our sample. ${ }^{7}$ Not surprisingly, they make almost exclusive use of the vernacular variant. 
TABLE 4. Results for Marie

\begin{tabular}{lrr}
\hline \hline Context & Je...ons & \multicolumn{1}{c}{ On } \\
\hline Narrative & $21(83 \%)$ & $3(17 \%)$ \\
Nonnarrative & $6(4 \%)$ & $156(96 \%)$ \\
\hline \hline
\end{tabular}

Although only $18 \%$ of the Abram-Village tokens contained the vernacular variant je...ons, both the overall results and the quantitative results by social category mask the fact that what seems to be a declining vernacular variant is not simply fading away. In the following section we examine variation in the usage of individual speakers in this community.

VARIATION AT THE LEVEL OF THE INDIVIDUAL

Close inspection of the interviews shows that some Abram-Village speakers have near-categorial or categorical use of on. For example, one resident, Elizabeth, ${ }^{8}$ a 35-year-old secretary at the local French-medium high school, used $99 \%$ on, and another, Michel, a 21-year-old accountant with many contacts outside the community and outside of Évangéline, had only on tokens. Their avoidance of je...ons conforms to their high marketplace ranking. For them, je...ons is stigmatized. However, when we examine the data for Abram-Village speakers with mixed usage, we find that a discourse-level constraint is operative in several cases. For such speakers, je... ons predominates in narrative contexts, whereas on predominates in nonnarrative contexts.

To illustrate this difference, we turn to some of the Abram-Village individual interviews in detail, beginning with Marie, who was 81 at the time. Marie had gone to school up to grade seven, not atypical for her generation. In her younger days, she had cleaned other people's houses for a living; in 1987, at the time of the interview, she lived in the local seniors' home. Her interview lasted for 90 minutes and covers a wide variety of topics concerning habitual aspects of life in her community, including her family history, childhood games, school, celebration of Christmas and other calendar customs in the old days, her early years of marriage, and, finally, life at the home. The interview contains 159 on tokens and $27 \mathrm{je} . .$. ons tokens. Twenty-one, or $83 \%$, of Marie's je...ons tokens occur in the six narratives that she recounted during the interview, five of which were quite short. The numerical results are displayed in Table 4.

Marie's wedding day narrative is reproduced next. Following Labov and Waletsky (1967) and Labov (1997), each clause is identified by structural type (i.e., abstract, orientation, complicating action, coda, or evaluation). 


\section{Marie's Wedding Day Narrative}

\section{Orientation}

1 C'était un gros frette, je nous avons marié le sept de février.

Il faisait frette!

Il y en avait [...] la fille-suivante puis le garçon-suivant.

5 Puis moi, je voulais faire ça en avant de l'église,

il faisait assez frette quand j'avons arrivé à l'église.

Dans ce temps-là, c'était le vieux Père Gallant.

\section{Complicating Action}

J'avons arrivé à l'église, il partait pour aller administrer à un vieux qui se mourait.

\section{Orientation}

Puis dans ce temps-là, fallait aller à l'église pour le matin pour la messe à sept heures.

10 Puis là, j'ons été obligé de rester là jusqu'à onze heures, avant qu'il ait été [...] - c'était à cheval - avant qu'il était rendu.

C'était à Ro-, fallait qu'il alle à Rocky Point.

\section{Complicating Action}

J'ons resté à l'église,

je faisions du feu [.?.] tout l'avant-midi.

J'avons arrivé chez nous, il était après douze.

15 J'avons, j'avons dîné chez nous

puis là, j'ons été souper su sa mère à lui.

Puis j'avons revenu chez nous pour la danse après ça.

\section{Marie's Wedding Day Narrative - Translation}

\section{Orientation}

1 It was really cold,

we got married the seventh of February.

It was cold!

There was $[\ldots]$ the maid of honour and the best man.

5 And me, I wanted to do that before church [started], it was pretty cold when we arrived at the church.

In those days it was old Father Gallant.

\section{Complicating Action}

[When] we arrived at the church, he went to give the last rights to an old man who was dying.

\section{Orientation}

And in those days you had to go to the church in the morning for seven o'clock mass. 
10 And then, we were obliged to stay there until eleven o'clock, before he came $[\ldots]$ - it was on horseback - before he was back.

It was at Ro-, he had to go to Rocky Point.

Complicating Action

We stayed at the church,

we had a fire going all morning.

We arrived home, it was after twelve.

15 We had, we had dinner at our house

and then we had supper at his mother's.

And we went home for the dance after that.

The wedding day narrative involves going to the church, finding the priest absent, waiting for hours until he returns from performing last rites, getting married at last, and then going home for the wedding meal and dance. This narrative contains ten instances of the variable, all with the je... ons variant; both orientation and complicating action clauses are involved. Je...ons is the only variant that occurs in five of Marie's six narratives. (In the sixth, there are three orientation clauses with on.) In contrast, when Marie is talking outside the narrative context, the vast majority of tokens contain on (156/162), as shown next in two other excerpts, one about dating when she was young and the other about cardplaying at the home.

\section{Extract 1 (Dating):}

Ça course jeune asteure, bien plus jeune que je coursions, nous-autres.

(Ah oui?)

On coursait pas si jeune que ça, nous-autres.

(Quel âge que vous aviez quand que vous avez commencé à -)

Ah bien, je devais avoir seize ans dans ce temps-là quand j'ai commencé à sortir.

Puis euh, on sortait pas non plus sans aller demander à son père, puis à sa mère, voir si on pouvait sortir. Asteure, asteure, je pense qu'ils demandont pas.

\section{Extract 1 (Dating):}

They chase after the boys young today, a lot younger than we used to chase after them, us.

(Yes?)

We used to chase around not as young as that, us.

(How old were you when you started to - )

Well, I must have been sixteen in those days, when I started going out. And uh we didn't go out without asking our father, and mother, to see if we were allowed to go out. Now, now, I don't think they ask.

\section{Extract 2 (Cardplaying):}

Des fois, on joue à la crib. D'autres fois on joue aux deux cents.

(C'est ti, c'est ti des femmes contre les hommes ou c'est ti - )

Oui. 
TABLE 5. Results for Daniel

\begin{tabular}{llr}
\hline \hline Context & Je ...ons & \multicolumn{1}{c}{ On } \\
\hline Narrative & $25(71) \%$ & $10(29 \%)$ \\
Nonnarrative & $10 \quad(4) \%$ & $214(96 \%)$ \\
\hline \hline
\end{tabular}

(C'est les femmes qui gagnent? T'es supposée de dire oui.)

Il y a des, il y a des soirs qu' on est des moyennes, des moyennes bandes à jouer aux cartes là puis $[\ldots]$ on $a$ de la fun.

\section{Extract 2 (Cardplaying):}

Sometimes we play crib. Other times we play two hundreds.

(Is it, is it women against the men or is it - )

Yes.

(The women win? You're supposed to say yes.)

There are, there are evenings when we are good-sized, good-sized groups to play cards and... we have fun.

Next, we turn to Daniel, 45 years old at the time of the interview and the owner of his own construction company. He completed grade 12 at the local high school, and at the time of the interview lived with his wife, Louise, the company bookkeeper, and their children in their own home. Daniel's interview likewise lasts 90 minutes and, like Marie's, covers a wide range of topics. It contains nine narratives. Quantitative results are shown in Table 5. Altogether, Daniel has 224 on tokens and $35 \mathrm{je} . .$. ons tokens.

Twenty-five of the je... ons tokens occur in narratives. In the narrative reproduced next, Daniel starts talking about the time he and his friends decided to play a trick on a neighbor one Halloween. They went to the neighbor's house around 9:30 PM, but the owners caught sight of them so they went back around two in the morning and played the trick. The next morning, the police were called and went out hunting for the culprits. Although Daniel and his friends didn't get caught, he got the scare of his life.

\section{Daniel's Halloween Tricks Narrative}

\section{Orientation}

1 Bien, la Halloween, oui.

La Halloween, c'était moins fêté que [...] que la Mi-Carême.

La Halloween, je sais pas, on faisait des, des [...] Jack-o-lanterns.

Il y avait des citrouilles puis euh [...]

(Oui. Avez-vous déjà fait des, des tricks su quelqu'un?) 
$5 \quad$ Ah oui! Nous-autres, je faisions trop de tricks quasiment.

(Conte-moi. Conte-moi-en.)

Hein? Hein?

Complicating Action

J'avions été su ce vieux icitte une soirée

\section{Orientation}

puis euh, c'était un gars qui, il farmait pas beaucoup bien il avait beaucoup de machineries chez zeux.

Je sais pas quoi ce-qu'il faisait avec toute avec ça.

\section{Complicating Action}

Puis j'avons arrivé là vers neuf heures et demie, dix heures

10 puis j'avons dit

\section{Orientation}

j'étions sept ou huit de nous-autres

\section{Complicating Action}

"J'allons toute prendre ces machineries

puis j'allons toute éparer ça partout dans la yard

puis j'allons faire un mess de sa maison."

\section{Evaluation}

15 Je sais pas comment ça se fait que je faisions ça.

C'était pas vraiment pas chrétien faire ça!

\section{Complicating Action}

Anyway, j'arrivons là

puis ils étiont toute debout

puis ils nous avont vu dans le jardin

20 puis nous-autres la peur nous prend

puis j'ons toute décollé.

J'avons dit: "Bien, je les laisserons faire.

Vers deux heures demain matin, je viendrons les, les prendre.

Là, je ferons le tour."

25 Puis j'avons été là

puis j'avions fait un tour.

J'avions toute éparé.

Le lendemain matin, ils s'avont levé puis c'était un mess partout.

30 Ils aviont callé les polices puis là, ils en aviont vu dans les jardins

puis là, les polices étiont dans les chemins.

Orientation

Puis je crois c'était la, la soirée [...] de Mi-Carême, de Halloween 


\section{Evaluation /Coda}

j'avais jamais eu si peur, je crois, parce-que [...]

Action (frame-out 1)

35 les polices, le lendemain matin, ils étiont dans les chemins

36 puis ils cherchiont les jeunes qu'aviont fait ça.

37 But oh, je sais pas, on faisait $[\ldots]$

Coda (frame-out 2)

38 Non, j'avons pas fait prendre.

\section{Daniel's Halloween Tricks Narrative - Translation}

\section{Orientation}

1 Well, Halloween, yes.

Halloween, it was less celebrated than [...] than Mid-Lent.

Halloween, I don't know, we used to have [...] Jack-o-lanterns.

They had pumpkins and uh [...]

(Yes. Did you ever play tricks on anyone?)

$5 \quad$ Oh yes! Us, we used to play almost too many tricks.

(Tell me. Tell me some.)

\section{Complicating Action}

We went to this old man's house one evening

\section{Orientation}

and uh, he was a guy who, he didn't farm very much even though he had a lot of machinery at their place.

I don't know what he did with all that.

\section{Complicating Action}

And we arrived there around nine-thirty, ten o'clock,

10 and we said

\section{Orientation}

we were seven or eight of us

Complicating Action

"We're going to take all your machinery

and we're going to spread it all around the yard

and we're going to make a mess of his house."

\section{Evaluation}

15 I don't know why we did that.

It wasn't really Christian to do that!

Complicating Action

Anyway, we arrive there, 
and they were all up

and they saw us in the garden.

20

And us, fear overtook us

and we all took off.

We said: "Well, we'll leave them alone.

Around two o'clock tomorrow morning we'll come back and take them.

Then we'll play the trick."

25 And we went there

and we played the trick.

We took everything apart.

The next morning, they got up

and there was a mess everywhere.

30 They had called the police

And then they looked in the gardens.

And then the police were cruising.

Orientation

And I believe it was the, the evening [...] of Mid-Lent, of Halloween

Evaluation /Coda

I had never been so afraid, I believe, because [...]

Action (frame-out 1)

35 the police, the next morning, they were cruising around,

36 and they were looking for the young people who had done it.

$37 \quad\left[\begin{array}{l}\text { (You got caught?) } \\ \text { but oh, I don't know, we used to }[. . .]\end{array}\right.$

Coda (frame-out 2)

38 No, we weren't caught.

In the first orientation section, there is a case of indefinite on, on faisait (line 3), not an instance of the variable. Beginning with line 5, there is a series of sixteen je...ons tokens, contained in orientation, complicating action, and evaluation clauses. After a second evaluation in line 34 (J'avais jamais eu si peur/ 'I had never been so afraid'), Daniel sums up, moving out of the narrative in lines 35 (les polices, le lendemain matin, ils étiont dans les chemins / the police, the next morning, they were cruising around') and line 36 (puis ils cherchiont les jeunes qu'aviont fait ça/ 'and they were looking for the young people who had done it'). In line 37, he says, oh, je sais pas, on faisait... / 'oh, I don't know, we used to...' and the interviewer overlaps with him with a question: Vous avez fait prendre?/ 'You got caught?'. Daniel then returns to a second frame-out (cf., Galloway Young, 1987), the coda, in line 38: J'avons pas fait prendre/ 'We weren't caught'. This on faisait/j'avons pas fait sequence is interpretable in terms of the interruption: the question momentarily returns him to the narrative frame. In the text that follows, Daniel clearly has moved on, and there are a number of on tokens immediately following the narrative. 
In another lengthy narrative, which likewise recounts events which took place when Daniel was a child, there are five on tokens and eleven je...ons tokens. The beginning and end of the narrative are found below. The on tokens occur at the beginning, in orientation clauses in lines 1 and 2 (Moi puis mon frère, on avait été voir pour une brouette/ 'Me and my brother, we went to see about a wheelbarrow'; On avait été su mon menoncle/ 'We went to my uncle's') and in a following evaluation clause in line 3 (puis c'est pour dire comment honteux qu'on était) 'and it's to give you an idea of how shy we were'). These are followed by eleven je... ons tokens, contained in complicating action clauses, such as in line 28 (puis je nous emmenons en courant par chez nous/ 'and we ran home'). The final instance of on occurs in line 30, in an evaluation/coda (C'est de même qu'on était, oui, on était pas mal honteux/ 'That's how we were, yes, we were pretty shy'). The variable usage displayed may be interpreted in terms of Daniel's framing in and out of narrative.

\section{Daniel's Borrowing the Wheelbarrow Narrative, Excerpt}

\section{Orientation}

1 Je m'en souviens une fois que [...] moi puis mon frère, on avait été voir pour une brouette.

On avait été su mon menoncle.

\section{Evaluation}

Puis c'est pour dire comment honteux qu'on était.

Bien dans ce temps là, les [...] surtout les jeunes, le monde était plus honteux qu'il est...

5 Les jeunes aujourd'hui, bien, un gars qu'arrive icitte puis quand même s'il le connaîtra pas, il commencera à lui parler puis euh $[\ldots]$

Moi, mes enfants, c'est [...] je m'aperçois de ça, comparé quoi-ce j'étais, moi.

\section{Complicating Action}

J'avions été, j'avions été voir pour une brouette.

Je voulions une brouette su mon oncle, Léo.

10 So j'avons été là puis

j'avons arrivé au pont.

Ça fait boum, boum, boum

puis nous-autres, la peur nous prend

puis je nous emmenons en courant par chez nous

J'avions pas, j'avions pas emprêté la brouette.

\section{Evaluation/Coda}

30 C'est de même qu'on était, oui, on était pas mal honteux.

C'était manière plus gêné. 


\section{Daniel's Borrowing the Wheelbarrow Narrative, Excerpt - Translation}

\section{Orientation}

1 I remember one time ... me and my brother, we went to see about a wheelbarrow.

We went to my uncle's.

\section{Evaluation}

And it's to give you an idea of how shy we were.

Well, in those days, the ... especially the young people, people were shyer than they are...

5 Young people today, well, a guy comes here and even though they don't know him, they'll talk to him and eh ...

Me, my children, it's ... I notice that, compared to how I was, me.

\section{Complicating Action}

We went, we went to see about a wheelbarrow.

We wanted [to borrow] a wheelbarrow at my Uncle Leo's.

10 So we went there

And we arrived at the bridge.

...

It went boom, boom, boom.

and us, fear overtook us

and we ran home.

We didn't, we didn't borrow the wheelbarrow.

\section{Evaluation / Coda}

30 That's how we were, yes, we were pretty shy.

It was sort of more embarrassed [than anything else].

On the other hand, outside the narrative frame, Daniel uses on almost exclusively, such as when telling of his and his wife's settling in Abram-Village, where he'd been born and raised, after their marriage, excerpted next. ${ }^{9}$

\section{Extract 3: Settling Down in Abram-Village}

Ma femme? Elle s'appelle X. On s'a marié dans dix-neuf cent soixante et six. Le trente de juillet, dix-neuf cent soixante et six.

(Mm hmm. I see. Comment-ce-que vous avez décide de venir à Abram-Village dans cette maison icitte ... pour rester, votre famille?)

Euh, c'était ... ça s'adonné [...] quand-qu'on s'a décidé, on restait à SaintChrysostome. Et puis euh, la, la famille qui restait icitte, c'était Y. Ielle, sa femme, ça se trouvait ma première cousine. Et puis elle était morte juste un an avant. Et puis, il nous a demandé de venir rester ... de venir rester avec lui. Puis tandis qu'on a venu rester avec lui, on s'a déci[...] lui s'a décidé de déménager à Summerside.

(Ah oui?)

Et puis nous-autres, on s'a décidé d'acheter sa maison. 


\section{Extract 3: Settling Down in Abram-Village - Translation}

My wife? Her name is X. We got married in 1966. The thirtieth of July, 1966. (Mm hmm. I see. How did you decide to come to Abram-Village in this house here ... to stay, your family?)

Eh, it was ... when we decided, we were staying in Saint-Chrysostome. And eh, the, the family was living here, it was Y. Her, his wife was my first cousin. And she had died the year before. And then, he asked us to come and stay ... to stay with him. And when we came to stay with him, we decid [...] he decided to move to Summerside.

(Oh yes?)

And us, we decided to buy his house.

We argue that Daniel and Marie's interviews reveal a pattern, whereby je... ons serves as a marker for the performance of narratives of personal experience. An objection that might be raised to this interpretation is that what we are calling narrative versus nonnarrative context might be more accurately considered as a formal versus informal contrast, recalling that in Labovian methodology, the elicitation of narratives of personal experience is a technique for getting at the interviewee's informal style. However, there are a number of arguments against this analysis of our data. First, the contrast obtains even when we consider highly reduced narratives, consisting of only three or four narrative clauses. Second, one good indicator of level of formality in the Acadian context is the frequency with which speakers use words (which they view as) of English origin. In the interviews on which this analysis is based, we detect no difference in such frequency in narrative versus nonnarrative contexts in the insider interviews that serve as our data base.

In Verbal Art as Performance, Bauman (1977:17) discussed the culturally conventionalized means by which members of a speech community key the performance frame. The communicative resources employed may include, among others, figurative language, special paralinguistic features, special formulae, and special codes. Special codes may involve "one or another linguistic level or features". In the present instance, use of a particular grammatical variant keys the performance of a specific verbal genre, narration. Je...ons is available for such use, as it is, in Cornips and Corrigan's (in press) terms, a low-level morphosyntactic variable, open to social (re)evaluation in a way that high-level variables (e.g., passivity) might not be. In our corpus, narration usually involves narratives of personal experience, but also includes family and community narratives. ${ }^{10}$ Because the variable at issue involves first-person plural reference, unsurprisingly it occurs most frequently in narratives of personal experience.

What of other Abram-Village residents who show mixed usage? In terms of the presence or absence of discursive constraints, two other types of speakers emerge. First, there are speakers who use a significant number of je... ons tokens overall. This is the case of Carole, an 18-year-old high school senior, who uses the traditional variant $80 \%$ of the time. Her interview contains two narratives, both of which have je...ons, not on. ${ }^{11}$ That Carole, an educated young woman, would 
TABLE 6. Results for Sylvie

\begin{tabular}{llr}
\hline \hline Context & Je ...ons & \multicolumn{1}{c}{ On } \\
\hline Narrative & $34(59 \%)$ & $24(41 \%)$ \\
Nonnarrative & $15(8 \%)$ & $182(92 \%)$ \\
\hline \hline
\end{tabular}

have such a high frequency of use of the vernacular variant is not surprising. As Flikeid (1992) argued, education level alone gives us an incomplete picture of Acadians' relative sensitivity to the relationship between standard and vernacular usage. It does not take into account the various ways in which one is exposed to standard varieties, for example, through contact with outsiders, through jobs that may be interpreted as low in terms of one's socioeconomic status, but that bring one into contact with, or require, use of the standard or legitimized language. We suggest that Carole's age indicates a lack of life experience needed to recognize the sociosymbolic meaning(s) of the two variants.

Second, there are speakers for whom the narrative/nonnarrative split is not as clear as in the case of Marie and Daniel, but who do tend to use je...ons in narrative. This is the case for Sylvie, a 42-year-old letter carrier and amateur actor, who uses this variant $23 \%$ of the time. Her interview contains eleven narratives and her use of the variable is shown in Table 6. Here we see a high proportion of on tokens overall, but with je...ons is found somewhat more frequently than on in narratives. However, turning to the individual narratives, we find that two of the eleven have only on tokens, ten such tokens in total. In the remaining nine narratives, there are fourteen on tokens and thirty-four je...ons tokens. In these narratives all but one clause containing complicating action have je... ons. ${ }^{12}$ On is limited to orientation and evaluation clauses (sometimes evaluation and coda clauses combined) near the beginning or end of the narrative. Thus, in the majority of Sylvie's narratives, the pattern is similar to what was found for Daniel. One might ask why she is more "advanced" than Daniel, an Abram-Village resident of around the same age. More specifically, why has on "taken over" in two of her narratives? The answer most likely lies in Sylvie's participation in voluntary activities involving frequent contact with speakers of external varieties. As an actor in local summer theatrical productions, she has significant contact with francophone tourists, particularly tourists from Quebec, for whom on is the only informal variant (cf., Laberge, 1977). These results, then, show that a particular declining variant is not simply fading away. Some Abram-Village speakers have abandoned the traditional variant je...ons, while others continue to use it quite frequently. But for some mixeduse Abram-Village speakers, it has taken on a new function in discourse, that of indexing the performance of narratives of personal experience, a function observable in a stylistically rich database. 
In general, then, contact with other varieties leads certain Acadian French forms to be viewed as substandard. Abram-Village speakers make less frequent use of the vernacular variant, and consequently, use on to a greater extent. However, participating in an education system that extols the virtues of the standard variety results not in widespread use of the standard variant nous, but, rather, in the stigmatization of the traditional variant, je...ons, and rise of the colloquial French on. Saint-Louis speakers, on the other hand, have had little contact with other varieties; they do not appear to consider je...ons to be stigmatized and therefore make frequent use of this form. But stigmatization is only part of the je...ons story. For some Abram-Village speakers, rather than being stigmatized, je... ons has instead become associated with a particular discourse function, that of indexing the performance of oral narrative.

We noted previously that our results confirm a general tendency in Acadian varieties for the first-person vernacular variant je...ons to be less well preserved than the third-person form, ils ... ont. It is safe to say that $i l s . .$. ont $(76 \%$ of occurrences of the third-person plural variable) has not undergone the fate of je...ons (18\% of occurrences of the first-person plural variable) in Abram-Village. We suggest that this discrepancy occurs because the contrast between the vernacular and nonvernacular forms is more marked in the first-person plural than in the third-person plural. A comparison of the two cases shows that what differentiates the two variables is that the first-person variable involves a change in pronominal clitic along with loss of a suffix on the verb (e.g., je parlons vs. on parle), while the third-person case involves (uniquely) loss of the suffix (e.g., ils parlont vs. ils parlent). Further, the retention of the -ont suffix in the third-person plural may be reinforced by the occurrence in the standard variety of high-frequency irregular verbs with -ont, such as aller "to go" - ils vont, être "to be" - ils sont, and avoir "to have" - ils ont. The fact that the first-person plural vernacular variant is highly distinctive, providing a marked contrast with the on variant, seems to be the motivation for its strong association with local norms and its reevaluation, either as a performance key or as a stigmatized variant.

\section{N OTES}

1. There is variation across Acadian French varieties as to whether the subject "pronouns" constitutes syntactic subjects or verbal affixes (cf., King \& Nadasdi, 1997; Balcom \& Beaulieu, 1998); we ignore this issue here.

2. All data cited come from the 1987 sociolinguistic interview corpus for Prince Edward Island French constructed under the direction of Ruth King.

3. Lodge (1998:114) showed je... ons remained in use in pre-Revolutionary Paris; further, the data in the Dialogues révolutionnaires suggest that it was widely used by members of the lower classes (both cited by Coveney, 2000).

4. Like je...ons, ils...ont is an example of archaic usage surviving in Acadian, appearing in France as early as the 13th century. According to Nyrop (vol. 2, no. 61), ils ... ont was in widespread usage in the center-west of France at the time of Acadian emigration from that area.

5. King \& Nadasdi (1996) provided a full discussion of the ils... ont variable in Prince Edward Island Acadian, and Dubois, King, \& Nadasdi (2003) provided a comparison of Atlantic Canada Acadian and Cajun usage. 
6. As we have not included data for French immersion students in this analysis, there are no younger speakers (i.e., between 15 and 21 years of age) in the Saint-Louis sample used here. We have found in other research that these young Saint-Louis residents do not control vernacular variants (King, 2000).

7. These results are in line with the results of King \& Nadasdi (1999), where the Saint-Louis women stood out from the rest of our consultants, in that case, as the most frequent and most innovative codeswitchers.

8. All names are pseudonyms.

9. Although this excerpt does involve the temporal sequencing of past events, it constitutes a report rather than a narrative, as no evaluation expressing the relevance of this account to the present discourse is provided (see Fleischman, 1990; Labov, 1972; Labov \& Waletzky, 1967).

10. Butler (1991) found that these three types of narratives predominated in his corpus-based study of narratives in a Franco-Acadian community in the mid-1980s.

11. Like many younger speakers, Carole does not produce as many narratives as do older residents. However, her high frequency of je... ons usage across discourse genres is our primary interest.

12. The tendency toward use of je... ons in clauses involving complicating action suggests that such usage may involve a foregrounding strategy. Hopper (1979:213) noted that it is "a universal of narrative discourse that in any extended text an overt distinction is made between the language of the actual story line and the language of supporting material which does not itself narrate the main events," referring to the former as foreground and the latter as background. We thank Jen Smith for pointing us toward this work.

\section{REFERENCES}

Balcom, Patricia, \& Beaulieu, Louise. (1998). Le statut des pronoms personnels sujets en français acadien du nord-est du Nouveau-Brunswick. Linguistica Atlantica 20:1-28.

Bauman, Richard. (1977). Verbal art as performance. Prospect Height, IL: Waveland.

Beaulieu, Louise, \& Cichocki, Wladyslav. (2003). Grammaticalisation et perte des marques d'accord sujet-verb en français acadien du Nord-Est du Nouveau-Brunswick. In Sandra Clarke (ed.), Papers from the $26^{\text {th }}$ Annual Meeting of the Atlantic Provinces Linguistic Association. St. John's: Memorial University of Newfoundland. 121-143.

Brunot, Ferdinand. (1967). Histoire de la langue française, volume II. Paris: Librairie Armand Colin. Butler, Gary. (1991). Saying isn't believing: Conversation, narrative and the discourse of belief in a French Newfoundland community. St. John's: Institute for Social and Economic Research.

Cornips, Leonie, \& Corrigan, Karen. (in press). Convergence and divergence in grammar. In Peter Auer, Frans Hinskens, \& Paul Kerswill (eds.), The convergence and divergence of dialects in contemporary societies. Cambridge: Cambridge University Press.

Coveney, Aiden. (2000). Vestiges of nous and the 1st person plural verb in informal spoken French. Language Sciences 22:447-481.

Dubois, Sylvie, King, Ruth, \& Nadasdi, Terry. (2003). What Acadians and Cajuns agree on: A comparison of third person plural marking. Paper presented at NWAVE-32, University of Pennsylvania.

Eckert, Penelope, \& McConnell-Ginet, Sally. (1992). Think practically and look locally: Language and gender as community-based practice. Annual Review of Anthropology 21:461-490.

Fleischman, Suzanne. (1990). Tense and narrativity. Austin: University of Texas Press.

Flikeid, Karin. (1989). Recherches sociolinguistiques sur les parlers acadiens du Nouveau-Brunswick et de la Nouvelle-Ecosse. In Raymond Mougeon \& Edouard Beniak (eds.), Le français canadien parlé hors Québec. Québec: Presses de l'Université Laval. 183-200.

(1992). The integration of hypercorrect forms into the repertoire of an Acadian French community: The process and its built-in limitations. Language and Communication 12:237-266.

Flikeid, Karin, \& Péronnet, Louise. (1989). N'est-ce pas vrai qu'il faut dire 'J'avons été'?: Divergences régionales en acadien. Français Moderne 57(3/4):219-228.

Galloway Young, Katherine. (1987). Taleworlds and storyrealms. Dordrecht: Martinus Nijhoff.

Hopper, Paul J. (1979). Aspect and foregrounding in discourse. In Talmy Givón (ed.), Syntax and semantics, volume 12: Discourse and syntax. New York: Academic Press. 213-241.

King, Ruth. (1989). Le français terreneuvien: Aperçu général. In Raymond Mougeon \& Edouard Beniak (eds.), Le français canadien parlé hors Québec. Québec: Presses de 1'Université Laval. 227-244.

(2000). The lexical basis of grammatical borrowing: A Prince Edward Island French case study. Amsterdam: Benjamins. 
King, Ruth, \& Nadasdi, Terry. (1996). Sorting out morphosyntactic variation in Acadian French: The importance of the linguistic marketplace. Sociolinguistic variation: Data, theory and method. Selected papers from NWAV23 at Stanford. Stanford: CSLI. 113-128.

(1997). Left dislocation, number marking and Canadian French. Probus 9:267-284.

(1999). On variable use of traditional Acadian morphology in Prince Edward Island French. In John Jensen \& Gerard van Herk (eds.), Proceedings of the Annual Meeting of the Canadian Linguistic Association. Ottawa: University of Ottawa. 169-178.

Laberge, Suzanne. (1977). Etude de la variation des pronoms sujets définis et indéfinis dans le français parlé à Montréal. Unpublished Ph.D. thesis, Université de Montréal.

Labov, William. (1972). Language in the inner city. Philadelphia: University of Pennsylvania Press. (1997). Some further steps in narrative analysis. Journal of Narrative and Life History 7:395-415.

Labov, William, \& Waletsky, Joshua. (1967). Narrative analysis. In J. Helm (ed.), Essays on the verbal and visual arts. Seattle: University of Washington Press. 12-44.

Lodge, R. Anthony. (1998). Vers une histoire du dialecte urbain de Paris. Revue de linguistique romane 62:95-128.

Mougeon, Raymond, \& Nadasdi, Terry. (1998). Sociolinguistic discontinuity in minority language communities. Language 74(1):40-55.

Nyrop, Kristoffer. (1889-1936). Grammaire historique de la langue française. (6 vols.) Paris: Picard.

Sankoff, David, \& Laberge, Suzanne. (1978). The linguistic market and the statistical explanation of variability. In David Sankoff (ed.), Linguistic variation: Models and methods. New York: Academic Press. 239-250.

Thibault, Pierrette. (1991). La langue en mouvement: Simplification, régularisation, restructuration. LINX 25:79-92. 